IRSH 56 (20I I), Special Issue, pp. 263-274 doi:I0.I0I7/S00208590 I I000447 (C) 20I I Internationaal Instituut voor Sociale Geschiedenis

\title{
Norms of Professional Excellence and Good Conduct in Accountancy Manuals of the Mughal Empire
}

\author{
NAJ A F H A IDER \\ Centre for Historical Studies, Jawaharlal Nebru University
}

E-mail: snajafhaider@yahoo.co.in

SUMmARY: In Mughal India, accounts were kept by individuals and institutions for purposes of reference and planning. Accountancy required a set of objectives and techniques for collecting, organizing, and presenting information so that it could then be put to use. It also fostered learning. Subsisting on formal or informal training, professional accountants equipped themselves with linguistic and mathematical skills, the art of notation, mnemonic devices, and the ability to translate loosely defined units into precise terms and numbers. Accountants were an important component of the state apparatus, village administration, and elite household management. In the seventeenth century manuals were produced in Persian by private individuals for the guidance of persons seeking to acquire proficiency in accountancy (siyaq) and clerical work. No study has been made so far of the manuals themselves nor of the people who compiled or used them. This introductory essay examines the manuals (generally titled Dasturu-l Amal) and the information they contain about the system of accountancy as well as about the professional ethics and norms of ideal behaviour of the secretarial class.

We know little about the attitudes of ordinary workers to their work in medieval India. As a rule they neither reflected upon nor organized their thoughts to set them down in books. It is from the writings of the literate elite that we may get some understanding of how work in general and professions in particular were perceived, through remarks framed usually either within a religious or a dominant intellectual tradition.

This short essay is about norms of work and good conduct among a group of professionals in Mughal India who remain too little studied even though they were responsible for producing and managing huge numbers of records; they also wrote manuals about themselves and their work. They were members of a secretarial class, notably accountants and recordkeepers, who flourished in the sixteenth and seventeenth centuries under the Mughal and later the British Empire.

In Mughal India individuals and institutions kept records and accounts to gather and preserve information for reference and planning. Record-keeping 
and accountancy required clear objectives and reliable techniques to collect, organize, and then present information so that it would be useful. The art of learning was developed too as professional record-keepers and accountants equipped themselves with linguistic and mathematical skills, the skills of notation, mnemonic devices, and the ability to translate loosely defined units into precise terms and numbers. Record-keepers and accountants were an important component of the state apparatus, elite household management, and village administration. We cannot put a number on their population but, given the size of the Mughal lower bureaucracy, it must have been quite large.

The two institutions which generated and preserved sizeable records of their transactions were the state and the market. Much like merchants, the state possessed goals which implied costs. Warfare, administration, and taxation placed sustained demands on officials to work out suitable proportions of power, efficiency, and resources and to draw up balance sheets of their goals and achievements, income and expenditure, investments and returns. Records of information needed during such evaluations helped the state better to rehearse conceptually its policies and actions. Tangible evidence of the association between curiosity and statecraft was the impetus given to secretarial work, record-keeping, statistics, and accountancy.

In the seventeenth century manuals, or model textbooks, were written which were known as Dasturu-l Amal (literally Book of Rules), and they were copied and circulated for the guidance of persons seeking to acquire proficiency in accountancy, clerical work, administrative procedures, and the duties of government officials. The manuals were written in Persian, the language of administration throughout the Mughal Empire, except for village accounts, for which local languages were used. With the exception of one work published in the nineteenth century, all the manuals exist only as manuscripts and they have been used by scholars for the information they contain about economic history or state administration. ${ }^{\mathrm{I}}$ However, neither the texts themselves nor their authors have ever been studied.

\section{STRUCTURE AND CONTENT}

The manuals are mostly anonymous, but they appear to have been written by professionals rather than scholars and may have been used by individuals at home and in colleges and workplaces as learning aids. The contents are organized and everything is stated clearly and precisely. The

I. Anonymous, Dasturu-l amal i Alamgiri [Manual of Alamgir] (Bihar, c.1659,), MS, British Library, Add. 6599, ff. Ia-I33a; Jagat Rai "Shujai" Kayath Saksena, Farhang i Kardani (Dhaka, I679,), MS, Maulana Azad Library, Aligarh, Abdus Salam, Farsiya 85/3 I 5; Anonymous, Dasturu-l amal $i$ Ilm $i$ Navisindagi [Manual of the Science of Accountancy] (Bengal or Orissa, last quarter of the seventeenth century), MS, British Library, Add. 6599, ff. I33b-I85a; Munshi Nandram, Siyaqnama [Book of Accountancy] (Allahabad, 1694-1696, Lucknow, 1879); Anonymous, Khulasatu-s Siyaq [Essence of Accountancy] (Punjab, 1703), MS, British Library, Add. 6588. 
approach is practical, and information is given to the extent that the writer thought was necessary for those learning record-keeping and accountancy with little or no knowledge of these arts, and who wanted to obtain a government job or a private job with an aristocrat.

The manuals are structured more or less uniformly. The subject matter is divided into several parts offering technical information relevant to the job, and, at least in one manual, there is a section on norms of professional excellence and ethics. ${ }^{2}$ The technical part usually discusses six themes, namely numbers, notions of time and calendars, accountancy, record-keeping, the duties of government officials, and statistical information about the Mughal Empire. An interesting aspect of one of the manuals is that it reproduces real documents and statistics as illustrations rather than preparing fresh model ones. Those particular documents, of an extremely important nature, have survived only in that manual.

The first part is usually on arithmetic and computation, which required a knowledge of Indian, Persian, and Arabic numerals, decimal values, modes of computation, multiplication tables, calculation of crop-yields, salaries, wages, and rates of interest, surface areas suitable for land, cloth, stone, wood, and so on, and tables to calculate agricultural land, units of weights and measures such as those for jewellers, goldsmiths, and grocers, currency exchange rates, and tables for calculating fractions of money. The second part deals with the reckoning of time and eras. The Mughal chancery employed various eras for dating documents, coins, and chronicles: the lunar Islamic or bijri, luni-solar Indian, and purely solar (Ilabi) eras, and the Turkish cycle of twelve years.

In the last quarter of the sixteenth century currencies, exchange rates, weights, and calendars were standardized. In i 584 a solar calendar was introduced (Ilabi era) in all government offices and almanacs and henceforth documents, seals, and coins carried the solar Ilabi year of 365 days and twelve months that began on the day of the vernal equinox. Each month had a fixed number of days calculated on the basis of the sun's entry into the zodiac station. The preference of the Mughal emperor Aurangzeb for orthodox Islamic practice brought the Islamic calendar back.

The third theme in the manuals is the principle and technique of accountancy. The information is of immense value to understanding the major transition in the language and techniques of accountancy that had wide-ranging implications for the secretarial class. According to the manuals, before I 584 all accounts were kept in the Indian style and based on the principle of chronology in a single account book (babi). The Iranian style of accountancy, based on Arabic strokes, words, and numerals, was introduced in government offices in 1584 . New clerks, accountants, and 
finance officers were appointed and new regulations for maintaining fiscal records were framed and put into practice.

The Iranian style of accounting required the use of a special technique of writing and organizing words and figures known as siyaq. In siyaq, the account was organized into lines, heads, and characters of fixed length, number, and terms. The lines, points, and surfaces had properties for organizing space. The system of notation used in accounting for administration and commerce was called raqam, in which numbers were written as monograms. The largest number of documents containing siyaq numerals to be found in archives anywhere in the world are the accounting records of Mughal India.

The fourth part of the manuals covers records. All medieval governments were capable of measuring and dividing everything from farm produce to patronage. However, from the last quarter of the sixteenth century, Akbar's administration implemented a series of measures to impart precision to the work of government, and increased the tendency to work with numbers, such as the division of the empire into manageable territorial units, and the control of them through multiple chains of command. The bureaucracy was organized into ranks with dual numbers; there was an obligation to maintain fixed quotas of soldiers and horses corresponding with numerical ranks, and the right to draw matching salaries from territories yielding predetermined cash revenues which were tabulated in a specially devised money of account. Mughal monetary policy was itself based on complex quantitative calculations.

A leading book on state regulations devotes a whole chapter to the duties of the state accountant and suggests that he should be righteous in his conduct, accurate in writing, and skilful in handling numbers. According to the standards set by a finance minister in the last quarter of the sixteenth century, accountants should observe state regulations and render clear statements. According to him, their business rested upon inquiry and investigation rather than conjecture and approximation. ${ }^{3}$

\section{THE SOCIAL IDENTITY OF THE SECRETARIAL CLASS}

For centuries in northern India scribes and accountants were Indians belonging to the three castes: Kayasths (clerks), Khatris (traders), and Brahmans (scholars and teachers). Among the three, Kayasths were the most prominent and are described in our sources generally as accountants. Even after the establishment of Muslim rule there was no change either in the language of administration at the provincial level or in the social composition of the secretarial class, since very few senior state officials, 


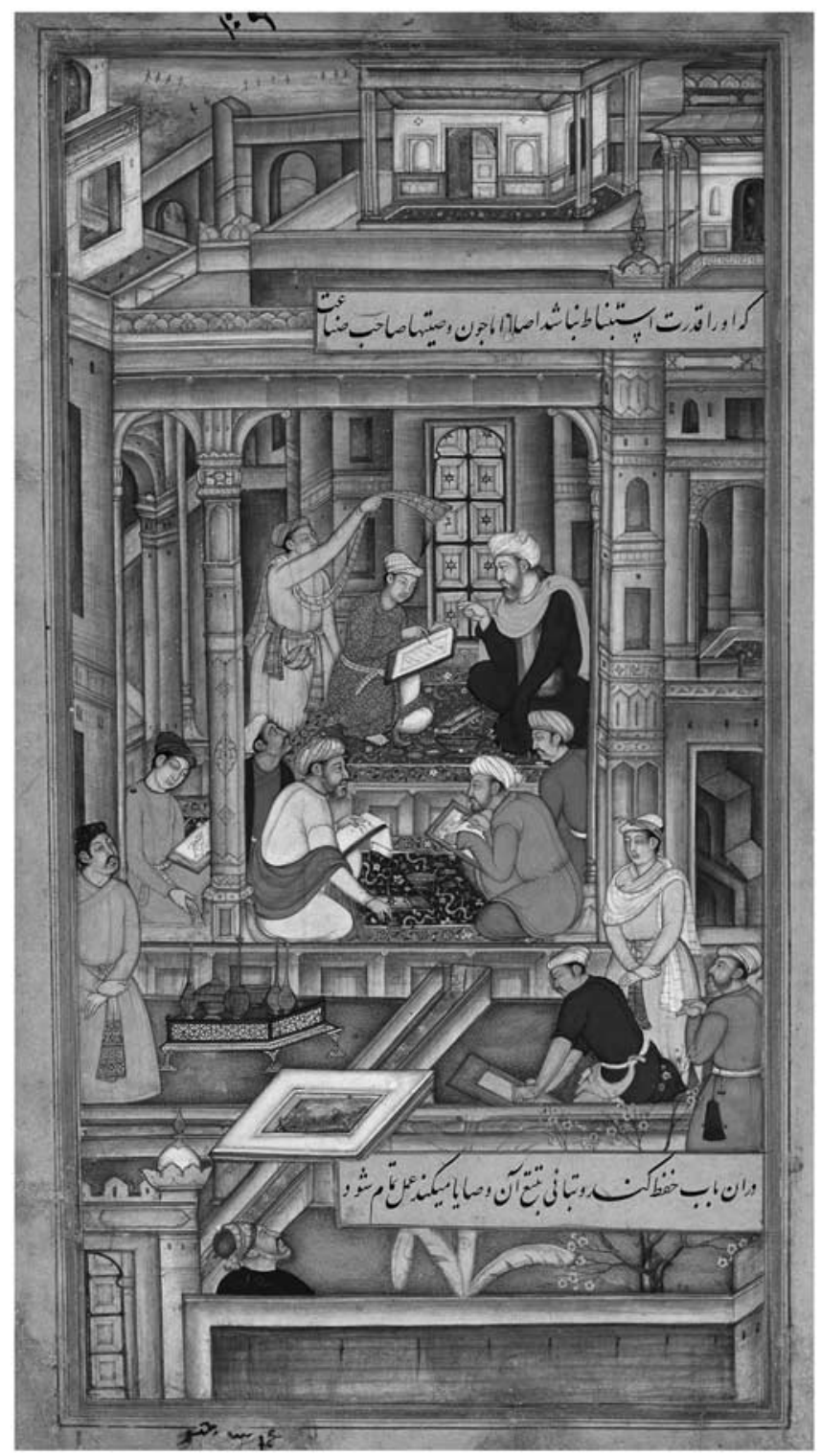

Figure I. Image of a Mughal scriptorium (kitabkhana) showing the arts of writing, painting and paper-making. In the main frame, a teacher dictates a text to a pupil (possibly a prince), while on the platform below a scribe works on a scroll even as he exchanges glances with a painter. The painting illustrates the text of Akblaq $i$ Nasiri, a thirteenth-century Persian work on ethics and politics that was kept in Akbar's library and read out to him. The inscription at the bottom of the painting reads "Amal S[ur] Jiv" [work of Sur Jiv].

Aga Khan Trust for Culture, Geneva. Used with permission. 
who were mostly Turks, Afghans, Iranians, or Central Asians, were familiar with the Hindwi language and script.

In the second half of the sixteenth century, there was a concerted attempt to make Persian the sole language of state records at all levels except for the village, and the man credited with bringing in the change was an Indian minister appointed by Akbar, Raja Todar Mal (d. I 589), who had himself excelled in both the Indian and Persian traditions of record-keeping and accountancy. The change must have had implications for the existing secretarial class insofar as huge numbers must have lost their jobs. They came back to great effect by learning Persian and the new system of accountancy so that they could compete among themselves and with Muslims for administrative positions. Members of the Hindu "intellectual" class, whose occupation was writing, and the secretarial and accountant castes were promoted in the bureaucracy of Akbar's time, a famous example being Raja Todar Mal.

If the traditional account of the sixteenth-century changes in the language of administration is correct, then the systematization of the state apparatus might have created opportunities for the secretarial class to learn Persian and acquire the new techniques of accountancy to get into the lower bureaucracy. Even though the older class of accountants and record-keepers came back, the Indian system of accountancy and recordkeeping was replaced by a new Perso-Islamic system. ${ }^{4}$

\section{ACCOUNTANTS AND THEIR EDUCATION}

In Mughal India there were many places where one could be educated to take up a profession: home, school, at the house of a teacher-scholar, and in the workplace. The children of merchants were equipped with elementary mathematical skills, probably at home. A French jeweller who made frequent visits to India over a span of two decades and who was quite familiar with the customs and traditions of the mercantile class made the following observation:

They [merchants] accustom their children at an early age to shun slothfulness, and instead of letting them go into the streets to lose their time at play, as we generally allow ours, teach them arithmetic, which they learn perfectly, using for it neither pen nor counters, but the memory alone so that in a moment they will do a sum, however difficult it may be. [They use the same] figures in their books, both in the Empire of the Great Mogull [Mughal], as well as in other parts of India, although the languages may vary. ${ }^{5}$

We know from the autobiography of a Jain merchant, Banarasidas, who flourished in the first half of the seventeenth century, that he went to

4. Khulasatu-s Siyaq, ff. 64b-65a.

5. J.B. Tavernier, Travels in India, V. Ball (trans.), 2nd edn, revd W. Crooke, 2 vols (London, I925), II, pp. I43-I 44 . 


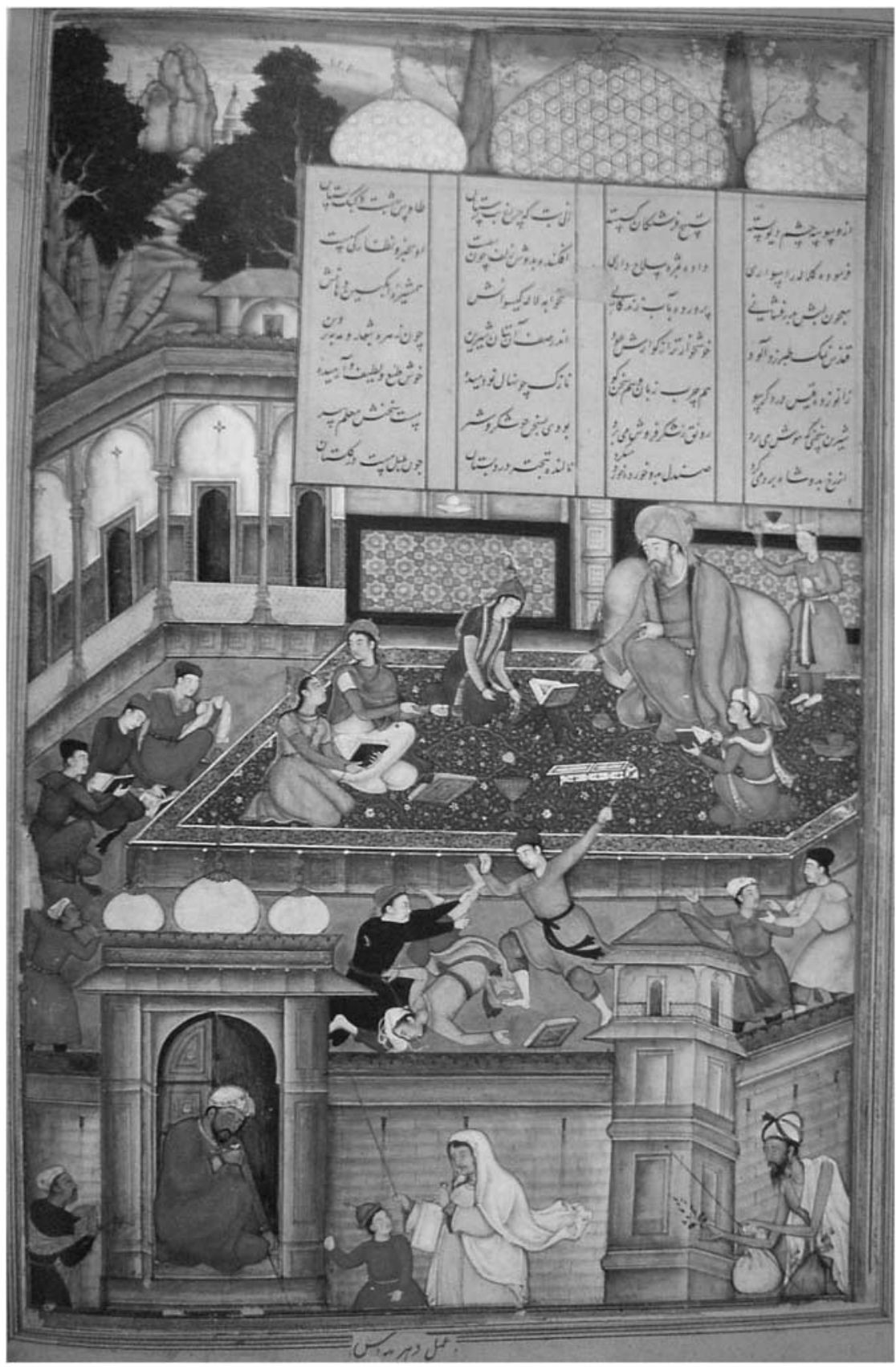

Figure 2. Scene from a school (madrasa); painting by Dharamdas.

MS, Khamsa of Amir Khusrau, Walters Art Gallery, Baltimore, no. 10,624, f. 98. Used with permission. 
school when he was eight. After finishing school, he learnt money testing (evaluation of the weight, fineness, and exchange rate of coins) and accountkeeping at home and in the market. ${ }^{6}$ The restructured school syllabus of Akbar's reign had a special focus on the science of numbers - computation (bisab), arithmetic (bindisa), mathematics (riyazi), and mubabat, which was something akin to civil engineering or the "construction and repair of buildings" - and included accountancy (siyaq) as a subject. ${ }^{7}$

Training in accountancy could be acquired from a professional working in an office. In another autobiographical account, a Brahman petty official named Balkrishan tells us that accountancy was his family profession, and he too was sent to the elementary school run by a Muslim teacher to read Persian books and acquire proficiency in all the rules of the language and letter composition. When he was older he was taken out of the school and attached to the department of a city official to learn arithmetic and accountancy.

I found the task dull and uninviting but did not give it up out of respect for my brother. My heart was still in literature and often in place of figures I saw verses [...]. But my brothers counselled me and told me that it is easy to earn money (naqd) in accountancy from the start whereas in letter writing one has to wait far too long to get a job. I would be unwise, I was told, to forego cash for credit. ${ }^{8}$

Balkrishan had a passion for learning. In his own words, he burnt the midnight oil and did not rest for a moment. It served him well in his career. Despite his brothers' gloomy predictions he managed to get employment as a revenue official, and was once even promoted too.

\section{NORMS PRESCRIBED FOR THE SECRETARIAL CLASS}

The recommendations (nasihat) given to prospective professionals appear in only one manual. ${ }^{9}$ The author mentions that he has collected them in one place from the dispersed writings of Iranian masters drawn from several sources. The section on recommendations has two components: the first relates to the general and special qualifications necessary for them, and can be classified as professional norms. The second component is about ethical standards and good conduct.

In the first part five essential qualifications are laid out for anyone to become a member of the secretarial class as well as to aspire to higher positions. The first is the art of writing, known as insha, notably the art of

6. Banarasidas, Ardhakathanaka [Half a Tale], Mukund Lath (ed. and trans.) (Jaipur, I98 I), p. 227.

7. Abu'l-Fazl, A'in-i Akbari, I, p. 202.

8. Maktubat i Balkrishan Brabman [Letters of Balkrishan Brabman], MS, British Library Add. I6859, ff. 97a-b; Irfan Habib, Medieval India: The Study of a Civilization (Delhi, 2007), pp. $25 \mathrm{I}-252$.

9. Dasturu-l amal $i$ Alamgiri, ff. 23 b-24a, 39a-40a. 
composing letters and drafting documents. Letters, documents, and accounts each followed a more or less fixed format which by the seventeenth century had acquired consistency in different departments or regions of the empire. Knowledge of written Persian and its phraseology was therefore considered to be the basic requirement for secretarial jobs. We have seen in the case of Balkrishan Brahman that he was first sent to a teacher of Persian language and literature to acquire that basic knowledge and training.

The second quality the manual lays out is the knowledge of special techniques of accountancy (siyak), and the third a good knowledge of arithmetic (hisab). We have already discussed those two branches.

The fourth quality listed is fluency in spoken Persian. There were professionals in Mughal India who could understand but could not speak Persian. That was a definite handicap because in government departments high-ranking nobles usually held the superior posts while the lower bureaucracy was staffed with clerks, accountants, and petty officials. The high officials mostly spoke Persian with felicity, either because they were ethnic Iranians, Central Asians, or even Afghans, or because they had learnt the language to conduct administration. Since secretarial tasks involved paperwork as well as taking instructions and dictation from superiors, fluency in the spoken language was considered essential.

The fifth qualification mentioned is full knowledge of all types of record kept in the various departments (tax, mint, market, for instance) and all thirty-six workshops or ateliers (karkhana). Much like the modern Indian bureaucracy, the Mughal state generated immense amounts of paperwork. We know from the manuals themselves, as well as from surviving documents, that the numbers were huge and in many cases a single record was kept in many variations and recensions.

The manuals emphasize that proficiency and experience in the art of writing insha, accountancy, and record-keeping guaranteed excellence and upward professional mobility. It is said that skill is like a tree and performance its fruits. Performance was measured in terms of the ability to withstand the scrutiny of strict auditors (musatufi). The combination of the art of letter composition and accountancy was the ideal, but difficult to achieve. Chandrabhan Barhaman, letter writer to the Mughal emperor Shahjahan, advised his son Tej Bhan to learn, if he could, both letter composition and accountancy: "There are very few letter-composers (munshis) who know accountancy, and fewer among accountants who are letter-composers. One can outshine others by combining the two skills." ${ }^{\circ}$ In the testimony of the royal letter writer we have further evidence that the manuals did indeed reflect the reality of the profession.

Io. Chandrabhan Barhaman, Chahar Chaman [Four Gardens], Seyed Mohammad Yunus Jafery (ed.) (Delhi, 2007), p. I75. 
The section of the manual dealing with the conduct of life is interesting insofar as it has practically no direct connection with the profession itself except for its opening remark, which could perhaps be considered to be general. In fact, if we did not know the context it would be almost impossible to guess which professional group it is addressed to. It begins by prescribing that once a person had attained the age of twenty-one and acquired the five basic qualifications mentioned earlier he is ready to seek employment in the imperial administration or in the offices of the nobles. Once employed, he is required to serve his department with the utmost integrity and efficiency and retain the goodwill and cooperation of all his colleagues and subordinates.

A personal element is introduced into the professional norms with the advice that whenever he wishes a task to be satisfactorily carried out by his subordinates and servants he should issue instructions in the same way as he issues them to his children, politely and affectionately rather than authoritatively or harshly. At the same time he should not be totally dependent on his subordinates. He should verify whether the job had been well done and if not he should make amends.

The accountant and record-keeper was expected to follow a strict and organized routine. During the last quarter of the night, just before the twilight brightened into dawn, he was expected to get up, bathe, and perform his religious rituals, puja, or any other form of worshipping God. The reference especially to the Hindu form of worship (puja) suggests the religious identity of the core audience of the manuals. Once the sun was up, he was advised to eat something and get on with his day's work. Work was important but the day was not devoid of leisure (fursat), the time spent with his friends and family after finishing work. In the first quarter of the night, before he went to sleep, he was reminded to pray once again. It was strongly advised not to sleep in the first and last quarters of the night. These were the times when angels roamed the earth and blessed those found in the act of worship and protected them from calamities and adversities. The angels condemned all those who were found whiling their time away.

That is once again an interesting piece of advice, since the concept of angels is Islamic and alien to Hinduism. The manner in which Islamic norms became assimilated into the religious-ethical world of a largely Hindu professional group signified the transition that took place from a purely Indic system of accountancy and record-keeping to the PersoIslamic one now practised predominantly by Hindu caste groups.

The contents of the section on recommendations becomes progressively more ethical and formulaic. Advice related to personal conduct and norms of social behaviour among professionals appeared in one manual as the virtue of the right sort of speech ("Do not speak more than is necessary and unless spoken to"); signs of good fortune (nek bakbti), such as the desire to seek knowledge (talib $i$ ilmi), generosity (sakhawat), a pleasing 
countenance (literally a smiling face), truthfulness, good deeds, making an effort to gain employment (koshish $i$ kasb), and generosity towards family members ("Do not accumulate but consume wealth"); and signs of misfortune (bad bakbti), such as sloth (kahili), harshness (sakbt rui), and pride (takabbur). The list of recommendations then goes on as follows:

(I) Treat your parents and guardians with kindness and gratitude. Do not curse your children. If you find your friends and acquaintances in trouble, try to help them rather than make excuses.

(2) Do not put (too much) trust in the good will of the king, governor, and employer.

(3) The things one should desire or seek in this world are consultations with the wise (mashwarat ba aqilan), avoidance of the company of women, keeping company with mendicants (darweshan).

(4) (a) Never accept or give out anything in trust deposit without a receipt (be sanad).

(b) Do not lend money to friends or borrow from them. It can destroy friendship.

(c) Treat your guests with warmth. Talk to them, offer them food and when they leave walk a few steps with them.

(d) Do good deeds all your life. Good and bad deeds influence the outcome of your actions in this world.

(e) Treat everyone with respect.

(s) (a) Do not travel alone or with strangers.

(b) Pay full attention to whatever you hear.

(c) Eat only halal food. While eating always give something from it in charity.

(d) Never bathe naked (barahna ghusl makun).

(e) Comb your moustache everyday (har roz mui ra shana kard).

(f) Look at your face in the mirror during the day but not at night.

(g) Do not stand guarantor to anyone. If you do, thoroughly examine the matter.

(h) Beware of three things: enmity (dushman), fire (atish), and debt (qarz).

I have reproduced a few norms as they appear in one manual without attempting to streamline or synthesize them. It is quite clear that they are fragmentary and lack systematization or organization of any kind, bordering on thought. Put together the whole section on ethics stands on its own. It seems as if our protagonists were living in two separate worlds, one professional and the other personal or social with no overlap. The professional world was defined by knowledge, skill, accuracy, and righteousness. The private social world was dominated by norms of good behaviour and various "dos and don'ts" drawn apparently from diverse sources. That appears to be the unique and characteristic feature of literature produced by a professional group, and such literature can be contrasted with 
the organized and orderly statements framed within certain well-established traditions about work and work ethics made by theologians and intellectuals and intended for the aristocracy. ${ }^{\mathrm{II}}$

\section{CONCLUSION}

It can be argued from a study of the manuals that there was a large market for professional accountants and record-keepers in the state sector. The bureaucracy of the state created regular employment for skilled professionals to work in various departments, as the Mughal bureaucracy and chancery followed a uniform procedure for creating and keeping accounts throughout its empire. Given the practice of transferring high officials from one department to another it was necessary for the state to have a uniform set of procedures and techniques that could be understood and followed by everyone everywhere. The procedures and techniques were predominantly Perso-Islamic methods adapted to the Indian situation.

In a certain sense it was a free labour market in which all adult males there is no evidence of women's participation in the profession - who were proficient in the Persian language and the art of accounting and record-keeping were able to be recruited and promoted. The professionals were mostly Hindus drawn from the secretarial and intellectual classes which had been serving the various imperial and regional administrations for centuries. Their willingness and ability to adapt to the new tradition symbolized the dynamic nature of the secretarial class, although the class itself seemed to have been limited to specific castes.

The manuals generally throw light upon themselves and the purpose for which they were written rather than upon the practitioners or how others perceived them. From internal evidence it seems that those practitioners perceived themselves as subordinate officials devoted to the task they were required to perform and to making their way up the occupational ladder by displaying professional excellence and adhering to a set of moral values to satisfy and please their patrons and superiors.

I I. Baqar Najm i Sani, Muiza i Jahangiri [Advice on Statecraft], Sajida Sultana Alvi (ed. and trans.) (Albany, NY, I989); Aziz Ahmad, "The British Museum Mirzanama and the Seventeenth Century Mirza in India", Iran, I 3 (1975), pp. 99-1 Io; see also Rosalind O’Hanlon, "Manliness and Imperial Service in Mughal North India", Journal of Economic and Social History of the Orient, 42 (1999), pp. 47-92. 